\title{
Pengaruh Pelaksanaan Metode Outdoor Learning dalam Pembelajaran IPS terhadap Motivasi Belajar Siswa SD PGRI Serui
}

\author{
Andi Nurhartina ${ }^{1}$ \& Isak Torobi ${ }^{2}$ \\ Program Studi PGSD, STKIP PGRI Papua, Indonesia \\ ${ }^{\square}$ E-mail: andinurhartina@gmail.com
}

\begin{abstract}
Abstrak
Tujuan penelitian adalah untuk (i) mengetahui gambaran pelaksanaan metode outdoor learning pada mata pelajaran IPS di SD PGRI Serui, (ii) mengetahui gambaran motivasi belajar siswa pada mata pelajaran IPS di SD PGRI Serui, (iii) mengetahui pengaruh pelaksanaan metode outdoor learning terhadap motivasi belajar siswa pada mata pelajaran di SD PGRI Serui. Jenis penelitian merupakan true eksperiment dengan rancangan pretest-posttest control group design. Penentuan kelompok eksperimen dan kelompok kontrol dilakukan dengan teknik systematic random sampling. Instrumen penelitian ini ialah rancangan pembelajaran dengan menggunakan teknik pengumpulan data yaitu lembar observasi guru dan siswa serta instrument angket. Data yang diperoleh dianalisis dengan uji normalitas dan homogenitas kemudian dilanjutkan dengan uji hipotesis menggunakan uji-t. Berdasarkan hasil penelitian, maka kesimpulannya; (i) Pelaksanaan metode ourdoor learning dalam pembelajaran pada mata pelajaran IPS siswa kelas IV dilaksanakan melalui 10 tahapan, dimana hasil observasi aktivitas siswa dan guru berada pada kategori baik; (ii) Motivasi belajar IPS siswa kelas IV setelah penerapan metode outdoor learning dalam pembelajaran mengalami peningkatan hasil belajar, dimana hasil belajar berada pada kategori tinggi; (iii) Ada pengaruh pelaksaan metode outdoor learning terhadap motivasi belajar IPS siswa kelas IV SD PGRI Serui.
\end{abstract}

Kata Kunci: Metode Outdoor learning; IPS; Motivasi.

\begin{abstract}
The research objectives were to (i) find out the description of the implementation of themethod outdoor learning in social studies subjects at SD PGRI Serui, (ii) to determine the description of student learning motivation in social studies subjects at SD PGRI Serui, (iii) determine the effect of implementing themethod outdoor learning on student learning motivation on subjects at SD PGRI Serui. This type of research is a true experiment with a pretest-posttest control group design. The determination of the experimental group and the control group was carried out using systematic random sampling technique. This research instrument is a learning design using data collection techniques, namely teacher and student observation sheets and questionnaire instruments. The data obtained were analyzed by means of the normality and homogeneity test then continued by testing the hypothesis using the t-test. Based on the research results, the conclusion is; (i) Implementingmethod ourdoor learning In learning on social studies subjects, grade IV students are carried out through 10 stages, where the results of observations of student and teacher activities are in the good category; (ii)motivation of Social studies learningfourth grade students after the implementation ofmethods outdoor learning in learning has increased learning outcomes, where learning outcomes are in the high category; (iii) There is an effect of implementing themethod outdoor learning on the social studies learning motivation of the fourth grade students of SD PGRI Serui.
\end{abstract}

Keywords: Method Outdoor Learning; IPS; Motivasi. 


\section{PENDAHULUAN}

Pendidikan memegang peran penting dalam mempersiapkan sumber daya manusia yang berkualitas. Untuk mewujudkan tujuan pendidikan nasional perlu diimbangi dengan peningkatan mutu pendidikan. Mutu pendidikan sangatlah erat kaitannya dengan mutu guru dan mutu siswa. Guru sebagai pengelola kegiatan pembelajaran merupakan faktor penentu kunci keberhasilan dalam pelaksanaan pendidikan. Pembelajaran yang terus berlangsung di dalam kelas membuat peserta didik sering merasa bosan dan tidak memiliki motivasi untuk belajar. Rutinitas peserta didik yang terkurun dalam ruangan secara terus menerus, dari pagi hingga siang, tetap memberikan efek buruk bagi mereka. Peserta didik tidak memiliki ruang gerak untuk dapat mengembangkan rasa ingin tahunya dan bereksplorasi seluasluasnya sehingga menyebabkan mereka kurang dapat belajar dengan maksimal. Kondisi tersebut jelas akan menimbulkan kejenuhan, baik bagi peseta didik maupun guru itu sendiri.

Salah satu aspek yang penting yang harus diperhatikan oleh guru adalah kurangnya motivasi siswa dalam belajar karena siswa menganggap mata pelajaran IPS merupakan (1) mata pelajaran IPS yang hanya berupa hafalan saja, membosankan karena harus menghafal secara tepat rentetan suatu peristiwa, waktu dan tempat juga metode yang digunakan oleh guru masih didoSD PGRI Seruiasi dengan menggunakan metode pembelajran konvensional yaitu metode ceramah dan tanya jawab. Hal ini mengakibatkan belajar bukanlah aktivitas yang menyenangkan bagi siswa dan hasilnya siswa tidak dapat menunjukkan kemampuan terbaik pada hal belajarnya karena siswa mudah melupakan materi yang telah dipelajarinya.
Menurut Diaz, menurut Syaiful (Sumantri, 2015:2) menjelaskan bahwa pembelajaran merupakan "Komunikasi dua arah, mengajar dilakukan oleh pihak guru sedangkan belajar dilakukan oleh siswa". Komunikasi dua arah ini yaitu interaksi umpan balik yang diberikan dari guru ke siswa dan begitu pun sebaliknya. Ditambahkan oleh Duffy \& Roehler (Amri 2013:229) yang menyatakan bahwa "Pembelajaran adalah suatu usaha yang sengaja melibatkan dan menggunakan pengetahuan profesional yang dimiliki guru untuk mencapai tujuan kurikulum". Menurut Duffy \& Roehler bahwa pembelajaran sangat melibatkan keterlibatan seorang guru profesional yang dalam proses pembelajaran agar mencapai tujuan kurikulum yang ingin dicapai.

Menurut Sumantri dkk (Yaba, 2009:5) "IPS sebagai bahan-bahan pelajaran ilmu-ilmu sosial yang sederhanakan untuk tujuan pendidikan di tingkat SD, SLTP, SLTA".

Ilmu Pengetahuan Sosial (IPS) merupakan salah satu mata pelajaran yang penguasaanya menuntut siswa menghafal materi yang telah disimpulkan, sehingga terkadang siswa merasa kesulitan dalam mengikuti proses pembelajaran. Akibatnya, siswa menampakkan sikap-sikap acuh dan malas. Perilaku siswa yang demikian tentu saja menunjukkan motivasi mereka terhadap pembelajaran IPS masih rendah. Motivasi yang masih rendah tersebut mungkin juga diakibatkan oleh faktor gaya mengajar atau metode mengajar yang diterapkan oleh guru.

Metode pembelajaran outdoor learning merupakan salah satu pembelajaran yang memanfaatkan sumber lingkungan sehingga pembelajaran dapat menarik dan menyenangkan dalam proses belajar mengajar dan juga dapat mengatasi kejenuhan siswa dalam menerima pembelajaran di kelas, karena melalui metode ini materi pembelajaran yang disampaikan didapatkan secara lansung 
dialami melalui di luar kelas sehingga siswa lebih dapat membangun makna atau kesan dalam memori atau mengingatnya. Dengan begitu banyak jam yang dihabiskan diluar kelas, lingkungan memiliki efek komulatif baik pada siswa maupun guru.

Dikatakan dalam beberapa hasil penelitian yang dilakukan oleh Faraziah (2015) tentang pengaruh penggunaan metode pembelajaran outdoor learning terhadap motivasi belajar siswa kelas IV dalam pembelajaran Ilmu Pengetahuan Sosial (IPS) di mana dalam hasil penelitiannya menyebutkan terdapat pengaruh penggunaan metode outdoor learning terhadap motivasi belajar siswa dalam pembelajaran IPS. Hal ini di buktikan dengan melihat skor rata-rata motivasi belajar siswa dengan menggunakan metode outdoor learning sebesar 57,34 dengan kualifikasi penilaian baik dibandingkan jika dengan melihat skor rata-rata motivasi belajar siswa yang menggunakan metode konvensional sebesar 44,63 dengan kualifikasi penilaian cukup.

Pemberian motivasi belajar oleh guru terhadap siswanya sangat penting dalam proses belajar mengajar agar terjadi pembelajaran yang menyenangkan. Berdasarkan sajian teori tentang metode pembelajaran outdoor learning yang dipaparkan oleh beberapa ahli, dapat di uraikan beberapa tahapan penerapan metode pembelajaran outdoor learning dalam pembelajaran IPS sebagaimana berikut: (1) kontrak pembelajaran, (2) penyampaian tujuan pembelajaran, (3) penjelasan materi pembelajaran, (4) menghadirkan permainan dalam pembelajaran, (5) menciptakan suasana persaingan belajar yang sehat, (6) memberikan kesempatan kepada siswa untuk memperlihatkan kemahirannya di depan siswa lainnya, (7) memberian pernyataan secara verbal dan non verbal, (8) merefleksi kegiatan pembelajaran.

Penelitian ini dilakukan di kelas IV karena pada jenjang ini siswa telah mampu berfikir sesuai dengan kenyataan di dalam kehidupannya. Siswa telah mampu menerapkan apa yang mereka dapatkan di dalam hubungan sosial mereka. Apalagi di dalam pembelajaran IPS di SD yang berfungsi untuk mengembangkan pengetahuan, nilai, sikap, dan keterampilan siswa tentang masyarakat, bangsa, dan negara Indonesia. Selain itu pembelajaran IPS berkenaan dengan pengenalan dan pemahaman siswa terhadap berbagai kenyataan sosial melalui pengenalan fakta, konsep dan penyusunan generalisasi, baik keluasan maupun kedalamannya yang dimulai dari lingkungan terdekat seperti keluarga hingga lingkungan terjauh seperti masyarakat. Dalam pembelajaran IPS siswa diberi kesempatan dan kebebasan mengembangkan keterampilan intelektual, keterampilan personal dan keterampilan sosialnya sehingga siswa diberi kesempatan berperan lebih aktif dalam mengelolah informasi, berpikir kritis dan bertanggung jawab.

Penulis melakukan penelitian terhadap mata pelajaran IPS karena berdasarkan hasil observasi awal penulis kepada guru kelas IV SD PGRI Serui pada tanggal 16 Februari 2017, ditemukan fakta bahwa saat proses pembelajaran IPS terdapat siswa yang bermain, bercerita dengan temannya dan tidak fokus pada pembelajaran sehingga nilai siswa dibawah nilai KKM yang menunjukan motivasi belajar siswa masih rendah dan juga melihat hasil dari daftar penilaian guru pada tahun ajaran 2016-2017. Dari rata-rata nilai ulangan harian menunjukkan bahwa hasil belajar siswa terutama pada mata pelajaran IPS tergolong masih rendah yaitu 60, nilai tersebut masih di bawah KKM (Kriteria Ketuntasan SD PGRI Seruiimal) yang ditetapkan SD PGRI 
Seruiimal 70.

Berdasarkan pengamatan peneliti hal itu terjadi karena kurangnya motivasi siswa dalam belajar karena siswa menganggap mata pelajaran IPS merupakan (1) mata pelajaran IPS yang hanya berupa hafalan saja, (2) membosankan karena harus menghafal secara tepat rentetan suatu peristiwa, waktu dan tempat juga metode yang digunakan oleh guru masih didoSD PGRI Seruiasi dengan menggunakan metode pembelajran konvensional yaitu metode ceramah dan tanya jawab. Hal ini mengakibatkan belajar bukanlah aktivitas yang menyenangkan bagi siswa dan hasilnya siswa tidak dapat menunjukkan kemampuan terbaik pada hal belajarnya karena siswa mudah melupakan materi yang telah dipelajarinya.

Berdasarkan permasalahan itulah peneliti ingin menerapkan metode pembelajaran outdoor larning sebagai salah satu solusi untuk memecahkan permasalahan yang ada. Alasannya menggunakan metode pembelajaran outdoor learning adalah proses belajaran cenderung fleksibel, lebih mengutamakan kreativitas dan inisiatif berdasarkan daya nalar dengan menggunakan alam sebagai media. Outdoor learning mampu memberikan pengalaman yang berkesan karena dalam pebelajaran peserta didik dapat memaksimalkan penggunaan indera yang mereka miliki demi mengembangkan rasa ingin tahu dan mencapai tujuan pembelajaran yang diinginkan. Outdoor learning juga mampu merangsang peserta didik untuk lebih kreatif dalam mencari alternatif pemecahan masalah. Sikap kemandirian, gotong royong,dan kerja sama juga dapat ditanamkan secara maksimal melalui pembelajaran outdoor learning. olehnya itu peneliti melakukan penelitian dengan judul Pengaruh Pelaksanaan Metode
Outdoor Learning dalam pembelajaran IPS Terhadap Motivasi Belajar Siswa SD PGRI Serui.

\section{METODE PENELITIAN}

Jenis penelitian yang digunakan yakni peneilitian kuantitatif jenis Quasi Eksperimental Design (eksperimen semu). Penelitian ini dirancang untuk mendapatkan pengaruh penerapan metode outdoor learning terhadap motivasi belajar siswa. Desain penelitian yang digunakan dalam quasi eksprimen ini adalah nonequivalent control group design yang menurut Sugiono (2010) melibatkan dua kelompok yaitu satu kelompok sebagai kelompok kontrol dan satu sebagai kelompok eksperimen. Hanya saja pada desain ini kelompok eksperimen maupun kelompok kontrol tidak dipilih secara random. Populasi yang dipilih sebagai subyek dalam penelitian ini adalah keseluruhan siswa kelas IV SD PGRI Serui semester genap tahun ajaran 2016/2017 yang terdiri dari kelas IV A dan kelas IV B. Adapun jumlah populasi dalam penelitian ini sebanyak 48 siswa (sumber data wali kelas IV SD PGRI Serui). Adapun jenis teknik pengambilan sampel yang digunakan terkait teknik non probability sampling ini yakni jenis purposive sampling. Merujuk pada hasil penarikan jumlah anggota sampel melalui penggunaan rumus Slovin maka ditetapkan, 43 orang siswa yang dapat dijadikan sebagai anggota sampel untuk masing-msing kelas. Instrumen penelitian yang diguakan terdiri atas dua yakni angket motivasi dan lembar pedoman observasi yang digunakan oleh peneliti sebagai alat bantu dalamproses pengumpulan data.

Teknik analisis data yang digunakan menggunakan teknik analisis data statistik deskriptif dan teknik analisis data statistik inferensial. Analisis statistik deskriptif digunakan untuk mendeskripsikan keterlaksanaan proses pembelajaran yang 
menggunakan metode ourdoor learning dan perubahan motivasi belajar IPS siswa yang dilihat dari hasil angket motivasi belajar yang diberikan menurut capaian nilai ratarata, nilai SD PGRI Seruiimum dan nilai maksimalnya. Teknik analisis statistik inferensial yang digunakan adalah analisis parametrik yang peruntukannya untuk menguji hipotesis. Statistik inferensial yang digunakan yaitu uji independent sample $t$ test pada taraf signifikan 0,05 dengan menggunakan program SPSS 22.0.0. Adapun kaidah pengujian yang digunakan dalam menguji hipotesis penelitian ini yakni: jika nilai sign. (2-tailed) $>\alpha$, maka Ho diterima (tidak ada perbedaan motivasi belajar siswa kelas IV pada mata pelajaran IPS yang menerapkan metode outdoor learning dengan motivasi belajar siswa yang menerapkan metode pembelajaran lainnya di SD PGRI Serui) dan jika nilai sign. (2-tailed) $\leq \alpha$, maka Ho ditolak (ada perbedaan motivasi belajar siswa kelas IV pada mata pelajaran IPS yang menerapkan metode outdoor learning dengan motivasi belajar siswa yang menerapkan metode pembelajaran lainnya di SD PGRI Serui).

\section{HASIL DAN PEMBAHASAN}

Penelitian dilaksanakan di SD PGRI Serui dengan subyek penelitian adalah 22 siswa kelompok eksperimen dan 21 siswa kelompok kontrol dari siswa kelas IV pada semester ganjil pada tahun pelajaran 2017/2018. Pada bab ini menyajikan gambaran mengenai hasil analisis data. Semua data yang diperoleh melalui instrument-instrumen penelitian dianalisis untuk menjawab pertanyaan penelitian yang ada pada rumusan masalah. Jawaban atas pertanyaan-pertanyaan tersebut dapat diperoleh dengan menganalisis data secara deskriptif dan inferensial.

Metode outdoor learning dalam pembelajaran merupakan metode yang dijadikan sebagai bahan perlakuan dalam peningkatan hasil belajar siswa. Penelitian ini dilaksanakan di SD PGRI Serui yang dimulai pada tanggal 7 Agustus - 7 September 2017. Pemberian perlakuan metode outdoor learning dilakukan sebanyak 4 pertemuan. dan pembelajaran konvensional juga 4 pertemuan. Sebelum menerapkan perlakuan, terlebih dahulu peneliti mengadakan pretest diluar jadwal pertemuan untuk penelitian. Setelah pertemuan dilakukan sebanyak 4 kali kemudian dilakukan posttest. Sebelum pelaksanaan metode outdoor learning diterapkan di kelas ekperimen terlebih dahulu dilakukan observasi pada siswa kelas IV untuk mengetahui data awal berkaitan dengan kemampuan siswa.

Gambaran motivasi belajar awal siswa (prestest) pada kelas eksperimen cenderung berada pada kategori kurang termotivasi sebab ada sebanyak 14 orang siswa dengan persentase $63,64 \%$ yang berada pada interval penilaian skor 51 sampai 73 . Tabel 1 berikut menggambarkan motivasi belajar awal siswa (prestest) untuk 22 orang siswa pada kelompok kelas eksperimen sebelum diberi perlakuan berupa penerapan metode outdoor learning dalam pembelajaran IPS.

Tabel 1. Data Motivasi Belajar Pretest IPS Siswa Kelas Eksperimen

\begin{tabular}{llll}
\hline \multirow{2}{*}{$\begin{array}{l}\text { Skor } \\
\text { Penilaian }\end{array}$} & $\begin{array}{l}\text { Pretest } \\
\text { Fensi } \\
\text { uensi } \\
(\boldsymbol{F})\end{array}$ & $\begin{array}{l}\text { Persen } \\
\text {-tase } \\
(\%)\end{array}$ & kategori \\
\hline $28-50$ & 0 & $0 \%$ & Sangat Tidak Termotivasi \\
$51-73$ & 14 & $63,64 \%$ & Kurang Termotivasi \\
$74-96$ & 8 & $36,36 \%$ & Cukup Termotivasi \\
$97-119$ & 0 & $0 \%$ & Termotivasi \\
$120-140$ & 0 & $0 \%$ & Sangat Termotivasi \\
\hline jumlah & 22 & $100 \%$ & \\
\hline
\end{tabular}

Sementara untuk gambaran motivasi belajar posttest IPS siswa kelas IV SD PGRI SERUI khususnya untuk kelas eksperimen setelah diberikan perlakuan berupa penerapan metode outdoor learning dapat diketahui 
dengan melihat sajian data tabel 2 berikut.

Table 2. Data Motivasi Belajar Posttest IPS Siswa Kelas Eksperimen

\begin{tabular}{llll}
\hline \multirow{2}{*}{$\begin{array}{l}\text { Skor } \\
\text { Penilaian }\end{array}$} & $\begin{array}{l}\text { Pretest } \\
\text { uensi } \\
(\boldsymbol{F})\end{array}$ & $\begin{array}{l}\text { Persen- } \\
\text { tase (\%) }\end{array}$ & kategori \\
\hline $28-50$ & 0 & $0 \%$ & $\begin{array}{l}\text { Sangat Tidak } \\
\text { Termotivasi }\end{array}$ \\
$51-73$ & 0 & $0 \%$ & Kurang Termotivasi \\
$74-96$ & 0 & $0 \%$ & Cukup Termotivasi \\
$97-119$ & 5 & $22,73 \%$ & Termotivasi \\
$120-140$ & 17 & $77,27 \%$ & Sangat Tremotivasi \\
\hline jumlah & 22 & $100 \%$ & \\
\hline
\end{tabular}

Tabel 2 menunjukkan gambaran motivasi belajar posttest siswa pada kelas eksperimen setelah diberikan perlakuan berupa penerapan metode outdoor learning mengalami peningkatan motivasi belajar secara signifikan di mana kecenderungan peningkatan motivasi belajarnya berada pada kategori sangat termotivasi sebab ada sebanyak 17 orang siswa dengan persentase $77,27 \%$ yang berada pada interval penilaian skor 120 sampai 140.

Gambaran motivasi belajar awal siswa (prestest) pada kelas kontrol cenderung berada pada kategori kurang termotivasi sebab ada sebanyak 12 orang siswa dengan persentase $57,14 \%$ yang berada pada interval penilaian skor 51 sampai 73 . Gambaran motivasi belajar posttest siswa pada kelas eksperimen setelah diberikan perlakuan berupa penerapan metode outdoor learning mengalami peningkatan motivasi belajar secara signifikan di mana kecenderungan peningkatan motivasi belajarnya berada pada kategori sangat termotivasi sebab ada sebanyak 17 orang siswa dengan persentase $77,27 \%$ yang berada pada interval penilaian skor 120 sampai 140.

Nilai rata-rata (mean) dari gain score motivasi belajar IPS siswa kelas IV SD PGRI SERUI pada kelas eksperimen (Mean $=124,0455)$ lebih termotivasi dibandingkan motivasi belajar IPS siswa pada kelas kontrol (Mean $=78,4762)$. Dari hasil perbedaan gain score ini membuktikan bahwa ada perbedaan motivasi belajar IPS siswa kelas IV SD PGRI SERUI antara yang diajar dengan penerapan metode outdoor learning dengan motivasi belajar siswa yang diajar dengan cara pembelajaran lainnya.

Begitu pula dilihat dari hasil pengujian hipotesis statistic Independent Sample T-Test seperti yang diperlihatkan pada tabel 4.8 di atas, diketahui nilai signifikansi $0,000<0,05$ sehingga dari hasil pengujian tersebut juga dapat diketahui bahwa ada perbedaan motivasi belajar IPS siswa kelas IV SD PGRI SERUI antara yang diajar dengan penerapan metode outdoor learning dengan motivasi belajar siswa yang diajar dengan cara pembelajaran lainnya.

Berdasarkan uji perbedaan tersebut, baik yang dilihat dari perolehan rata-rata gain score maupun berdasarkan hasil uji hipotesis statistik Independent Sample T-Test masingmasing menunjukkan bahwa ada perbedaan motivasi belajar IPS siswa kelas IV SD PGRI SERUI di mana letak perbedaannya yaitu motivasi belajar IPS pada kelas eksperimen lebih termotivasi dibandingkan motivasi belajar IPS siswa pada kelas kontrol. Olehnya itu, dengan melihat selisih perbedaan motivasi belajar dari kedua kelompok kelas tersebut dapat disimpulkan bahwa ada pengaruh penerapan metode outdoor learning dalam pembelajaran IPS terhadap motivasi belajar siswa SD PGRI SERUI.

\section{UCAPAN TERIMAKASIH}

Ucapan terima kasih diberikan kepada DPRM DIKTI atas dukungan pendanaannya demi kesuksesan penelitian ini. Peneliti juga mengucapkan terima kasih dan penghargaan editor yang telah menelaah dan mereview jurnal Papeda pada Vol 3, No. 1, Januari 2021. terima kasih kepada. 
KESIMPULAN

Berdasarkan hasil analisis data disimpulkan bahwa: (1) Pelaksanaan metode outdoor learning dalam pembelajaran IPS siswa kelas IV SD PGRI SERUI ditinjau dari aspek guru dan siswa dalam keterlibatannya dalam proses pembelajaran yang menerapkan metode outdoor learning mulai pertemuan I sampai pertemuan IV mengalami peningkatan secara berkelanjutan dengan kategori penilaian baik. (2) Motivasi belajar siswa kelas IV pada mata pelajaran IPS di SD PGRI Serui setelah diterapkan metode outdoor learning mengalami peningkatan motivasi belajar dengan kategori tinggi. Begitu juga pada kelas yang menerapkan metode pembelajaran lainnya, juga mengalami peningkatan motivasi belajar namun peningkatannya berada pada kategori sedang. (3) Ada pengaruh positif pelaksaan metode outdoor learning terhadap motivasi belajar siswa kelas IV pada mata pelajaran IPS di SD PGRI SERUI.

\section{DAFTAR RUJUKAN}

Amri, Sofan. (2013). Pengembangan dan Model Pembelajaran dalam Kurikulum. Jakarta: Prestasi Pustakarya.
Dalyono. (2009). Psikologi Pendidikan. Jakarta: Rineka Cipta

Farasiah, Riza. (2015). Pengaruh Penggunaan Metode Pembelajaran Outdoor Learning Terhadap Motivasi Belajar Siswa Kelas III Dalam Pembelajaran Ilmu Pengetahuan Sosial (IPS) Di Madrasah Ibtidaiyah Nurul Huda Pondok Karya Tangerang Selatan. Tesis. Tidak diterbitkan. Jakarta: Program Pascasarjana UIN Jakarta.

Hamalik Oemar, (2015). Proses Belajar Mengajar. Jakarta: Bumi Aksara.

Husamah. (2012). Pembelajaran Luar Kelas Outdoor Learning. Jakarta: Prestasi Pustakaraya.

Nashar. (2004). Peranan Motivasi dan Kemampuan Awal dalam Kegiatan Pembelajaran. Jakarta: Delia Press.

Sardiman. (2012). Interaksi \&amp; Motivasi Belajar Mengajar. Jakarta: Rajawali Pers.

Sumantri, S. (2015). Strategi Pembelajaran. Jakarta : Rajawali Pers.

Sugiyono. (2010). Metode Penelitian Pendidikan Pendekatan Kuantitatif, kualitatif dan $R \& D$. Bandung: Alfabeta.

Vera, Adelia. (2012). Metode Mengajar Anak di Luar Kelas (Outdoor Study). Jogjakarta: Diva Press.

Widiasworo, Erwin. (2017). Strategi \&amp; metode mengajar siswa diluar kelas (Outdoor Learning). Yogyakarta: ArRuzz Media 